\title{
Finding general patterns in complex water governance regimes
}

\author{
Claudia Pahl-Wostl $\cdot$ Andrew Ross
}

Received: 15 August 2010/Accepted: 16 August 2010/Published online: 3 September 2010

(C) Springer-Verlag 2010

The requirements for sustainable governance of environmental resources in general, and of water in particular, have been a topic of continued concern (Holling and Meffe 1996; Gleick 2003; Pahl-Wostl 1995, 2007). This ongoing debate has been fueled by prospects of climate and global change that render the conditions under which governance has to perform increasingly unpredictable (Bates et al. 2008). Globalization exhibits breath taking dynamics and leads to large-scale changes with unprecedented speed. Climate change and the concomitant increase of extreme weather events have exposed vulnerability of water resource governance and management regimes (Pahl-Wostl 2007; Pahl-Wostl et al. 2007; Opperman et al. 2009). At the same time, it is not clear how to achieve effective water governance, and many problems have not primarily been associated with the resource base but have to be attributed to governance failures.

Improving our understanding of how to achieve water governance is of paramount importance. There is increasing recognition that simplistic panaceas like privatization or decentralization as one-fit-all solutions to any governance problem are highly inappropriate (Ingram 2008; Ostrom 2007; Pahl-Wostl 2009). The papers in this special issue make a contribution to develop more general insights into governance approaches based on empirical evidence from a comprehensive assessment of case studies. They are based on papers given at the Conference on Adaptive and

C. Pahl-Wostl ( $\square)$

Institute for Environmental Systems Research, University of Osnabruck, Osnabruck, Germany e-mail: Pahl@usf.uni-osnabrueck.de

\section{A. Ross}

Fenner School of Environment and Society,

Australian National University, Canberra, Australia
Integrated Water Management, which was the first major international scientific event from and for the social science water community. The authors use different approaches from standardized comparative analysis to the in depth exploration of a single case study applying a general conceptual framework. All contributions explore the need to address complexity, the role of institutional diversity and the involvement of actors.

The paper by Huntjens et al. (2010) on "Climate change adaptation in European river basins" contains an assessment and standardized comparative analysis of the water management regimes in four case studies in three European river basins. This comparative analysis has an explorative character intended to identify general patterns in adaptive and integrated water management and to determine its role in coping with the impacts of climate change on floods and droughts. Despite its explorative character, the analysis offers very interesting insights. As expected from conceptual considerations (Pahl-Wostl 2007, 2009), the analysis showed a strong interdependence of the elements within a water management regime. For example, a lack of joint/ participative knowledge is an important obstacle for cooperation or vice versa - the two mutually dependent regime elements that were found to be of key importance. Furthermore, the research suggests that bottom-up governance is not a straightforward solution to water management problems in large-scale, complex, multiple-use systems, such as river basins. Instead, all the regimes analyzed were identified to be in a process of finding a balance between bottom-up and top-down governance. This is a clear indication of the need of a more balanced view of the interplay between different processes.

The contribution of Nikitina et al. (2010) on "Towards better water governance in river basins: some lessons learned from the Volga" focuses on the problems of water 
governance at a river basin level and on the role of institutional coordination, participation and partnerships between multiple stakeholders toward sustainable water management. They explore the potential of transfer and adaptation of good practices in good water governance between the EU and Russia.

Ross and Martinez-Santos (2010) examine in their paper on "The challenge of groundwater governance: case studies from Spain and Australia" the relevance of Ostrom's design principles for managing common property resources for analyzing groundwater governance. Based on the experience from four case studies, they conclude that while Ostrom's principles are relevant, more attention needs to be given to adaptive management and collaboration between governments, scientists, water suppliers and water users. Key management challenges include agreeing on and implementing sustainable levels of extraction, and establishing conditions for effective coordination and collaboration, monitoring and control.

In their contribution on "Management of catchments for the protection of water resources: drawing on the New York City watershed experience" Smith and Porter (2010) review the characteristics of 'wicked' environmental management problems and the specific policy challenges posed by diffuse water pollution. They use the example of the New York City watershed to exemplify elements of governance to deal with such problems with emphasis on local governance supported by multi-level partnerships and an enabling regulatory environment. They argue for the need to develop new models of governance for difficult land and water resource management problems and more empirical work following a general approach to develop knowledge base that allows deciding what are promising approaches of general validity.

The different contributions show clearly that despite case study-specific differences, some general patterns emerge. All papers agree on the importance of effective cooperation structures, adaptive approaches and multi-level governance. They also highlight the need for more comparative analyses to advance understanding to a point where conclusion can be drawn for meaningful contextsensitive policy advice instead of resorting to simplistic panaceas. There is a clear need to develop more inter- disciplinary and systemic approaches in the social sciences. Only by further developing and applying shared conceptual frameworks taking into account the real complexity of governance regimes will it be possible to build the knowledge base needed to lead to major advances in the understanding of these regimes.

\section{References}

Bates BC, Kundzewicz ZW, Wu S, Palutikof J (eds) (2008) Climate change and water. IPCC Sec, Geneva

Gleick P (2003) Global freshwater resources: soft-path solutions for the 21 century. Science 302:1524-1528

Holling CS, Meffe GK (1996) Command and control and the pathology of natural resource management. Conserv Biol 10:328-337

Huntjens P, Pahl-Wostl C, Grin J (2010) Climate change adaptation in European river basins. Regional Environmental Change. doi: 10.1007/s10113-009-0108-6

Ingram H (2008) Beyond universal remedies for good water governance: a political and contextual approach. 6th Rosenberg water policy forum. URL: http://rosenberg.ucanr.org/documents/ V Ingram.pdf

Nikitina E, Ostravskaya E, Fomenko M. 2010. Towards better water governance in river basins: some lessons learned from the Volga. Reg Environ Change. doi:10.1007/s10113-009-0092-x

Opperman JJ, Galloway GE, Fargione J, Mount JF, Richter BD, Secchi S (2009) Sustainable floodplain through large-scale reconnection to rivers. Science 326:1487-1488

Ostrom E (2007) A diagnostic approach for going beyond Panaceas. Proc Natl Acad Sci U S A 104:15181-15187

Pahl-Wostl C (1995) The dynamic nature of ecosystems: chaos and order entwined. Wiley, Chichester, p 288

Pahl-Wostl C (2007) Transition towards adaptive management of water facing climate and global change. Water Resour Manage 21(1):49-62

Pahl-Wostl C (2009) A conceptual framework for analysing adaptive capacity and multi-level learning processes in resource governance regimes. Glob Environ Change 19:354-365

Pahl-Wostl C, Sendzimir J, Jeffrey P, Aerts J, Berkamp G, Cross K (2007) Managing change toward adaptive water management through social learning. Ecol Soc 12(2):30

Ross A, Martinez-Santos P (2010) The challenge of groundwater governance: case studies from Spain and Australia. Reg Environ Change. doi:10.1007/s10113-009-0086-8

Smith LED, Porter KS (2010) Management of catchments for the protection of water resources: drawing on the New York City watershed experience. Reg Environ Change. doi:10.1007/ s10113-009-0102-Z 